in natural resources of many kinds. Trapping for furs has long been an established feature, and the Hudson Bay Company, formed so long ago as the year 1670 under the governorship of Prince Rupert, nephew of King Charles I., has carried on a prosperous trade for more than two centuries. The rivers teem with fish. Water power is plentiful and invites conversion at numerous falls into electricity for adaptation to various industries. Forests in the southern areas provide an abundance of timber, with the promise of extensive supplies of pulpwood for paper manufacture, in addition to the considerable number of trees available for constructional and commercial purposes.

Not less remarkable is the scope for mining minerals and precious metals. The great preCambrian area covering very nearly the whole of the Hudson Bay region, and known as the Canadian Shield, has given startling evidence of being one of the world's largest storehouses of mineral wealth. The famous Hollinger mine is third among the largest gold producers in both hemispheres. There are impressive copper-zinc ore deposits in northern Manitoba and massive bodies of ferriferous ore on the Belcher Islands in Hudson Bay.

The country is still largely in the exploratory stage, and much of its wealth yet remains to be discovered. From such evidence as has accumulated to date, it is clear that there is every ground for believing that the internal resources of the Hudson Bay region will prove highly remunerative and profitable to the capable prospector. The opening of the new ronte to Europe will afford a means of facilitating the initiation of further enterprise, and will doubtless lead to a great era of commercial, industrial, and agricultural development in the inland provinces of western Canada.

1 " Report on the Selection of a Terminal Port for the Hudson Bay Railway", October 1927.

2 "Report of the Hudson Strait Expedition, 1927-8." Ottawa, 1929.

\title{
Modern Whaling.
}

$\mathrm{SO}^{\mathrm{O} \text { far as historical records show, whaling was }}$ $D$ first begun in the twelfth century by the Biscayans in the Bay of Biscay. From that time until the beginning of the present century, all whaling stations were situated on land.

Towards the end of the nineteenth century, Svend Foyn had tried to operate a floating factory, but the venture failed. The next attempt in this direction was made by Commander Christensen when, in 1903, he sent a wooden steamer fitted as a temporary factory and accompanied by two attendant catchers to Svalbard (Spitsbergen). So much success attended this expedition that Christensen afterwards bought the steel steamer Admiralen and fitted her out as the first fully equipped floating factory. This proved to be an epoch-making vessel. In 1925 she was sent to South Georgia, accompanied by two catchers, and from that date the great modern Antarctic whaling era may be said to have begun. There are now one Argentine, three British, and four Norwegian companies operating at South Georgia, and seven Norwegian companies at South Shetland, in addition to various other shore and pelagic factories working elsewhere in the Antarctic.

Prior to the outbreak of the War, some twentyfour steamers had been converted into whaling factories, but all worked in or near harbours, depending - in part at least - upon water and other supplies from the shore. Since the War about the same number of ships have been converted, but the majority of the latter are designed to work in open seas entirely independent of any shore base. The pioneer in this field of development was the renowned whaler, Capt. C. A. Larsen.

Until roughly five years ago, all the working up of whales was done in the water alongside the factory ships, the blanket of blubber and severed pieces of the carcass being hoisted on board by winches and derricks. To avoid the labour and discomfort involved in such a trying and uneconomical method, by means of some kind of slipway which would enable the entire carcass to be hauled on board, had long been the dream of many a whaleman. Numerous suggestions were put forward and a number of ships fitted with various types of slipway. These were located in different parts of the vessels--from bow to quarter -but not one proved satisfactory. Not until the introduction of a straight slipway through the stern was success eventually achieved. The great obstacle in the way of a straight slip was the profound respect with which all sailors regard the stern frame and rudder post of a ship.

In 1925 the "Globus" Company bought the s.s. Flackwell (now Lancing) for conversion into a pelagic whaler. Mr. Chr. Fred Christensen, in cooperation with Capt. H. G. Melsom, supervised the reconstruction of this ship. With commendable courage they decided to make drastic alterations and arranged a straight and permanent slipway down to the waterline through the stern-a process which necessitated the cutting away of about eleven feet of rudder stock and stern frame post.

This revolutionary design proved highly successful, and has formed the model for all subsequent slipways. Improvements quickly followed until what the designers consider full efficiency was attained in the Vikingen - a new ship designed and built specially as a pelagic whaling factory at Messrs. Swan, Hunter and Wigham Richardson's Wallsend shipyard in 1928.

In a very valuable and intensely interesting handbook* just published, Mr. Christensen describes this ship. Plans of the vessel are given, along with detailed information regarding the arrangement of

* The Whaling Factory Ship Vikingen, with some Notes on Whaling. By Chr. Fred Christensen. (Newcastle-on-Tyne: North- Hast Coast Institution of Engineers and Shipbuilders, 1931.) Pp. $24+2$ plates. n.p.

$$
\text { No. 3219, VoL. 128] }
$$


the machinery and plant on board and the methods of working them. Photographs of the Vikingen and of her catchers at work are also included. To this are added a brief outline of the history of whaling and an account of various important modifications and improvements in whaling operations.

Mention is also made of the immense value of the whaling industry both to Norway and Great Britain. Since 1928, new factory ships totalling 140,000 tons and costing $£ 2,500,000$ have been built, excluding catchers. In addition to these new vessels, the whaling companies have bought in Great Britain about 250,000 tons of steamers for conversion into factories and transports. The approximate figures of expenditure in Great Britain during this period are :

Steamers converted into factories .

Floating factories (new buildings) .

Transport ships for factories

Repairs to all types of vessels

Whale catchers (new buildings)

$$
\begin{array}{r}
£ 1,000,000 \\
2,500,000 \\
950,000 \\
550,000 \\
2,200,000 \\
\hline £ 7,200,000
\end{array}
$$

Total .

In addition to the above, the purchase of coal, oil, and equipment in Great Britain has amounted to millions of pounds, and the British Government derives a large income from licences and duties paid by the companies on the oil and guano they produce.

G. A. S.

\section{Obituary.}

\section{Dr. Louis Dollo.}

$\mathrm{D}^{\mathrm{n}}$ R. LOUIS DOLLO, who died at Brussels on April 19, will always be remembered for his numerous and valuable contributions to our knowledge of extinct vertebrate animals. Early in 1882 he was appointed assistant-naturalist in the Royal Museum of Natural History, Brussels, where he afterwards became conservator, and was actively engaged in research until his retirement in November 1925. He arranged and labelled the unique collection of Belgian fossil vertebrates in the new museum which was opened in the Leopold Park in 1905 , and he published preliminary descriptions especially of the fossil reptiles in a series of remarkable papers, besides preparing a general guide-book to the vertebrates, both living and fossil.

Dollo was born at Lille on Dec. 7, 1857, and completed his education in the university of that city, where he graduated as a civil engineer. $\mathrm{He}$ studied geology under Prof. J. Gosselet, and he also devoted much attention to the zoological sciences both at Lille and in the marine biological station at Wimereux, under the direction of Prof. A. Giard. His inclination was towards natural history, and he abandoned an engineering career as soon as the opportunity for biological research presented itself in the appointment at Brussels in 1882. His early training, however, influenced him throughout life, and nearly all his writings are in the peculiarly mathematical form of brief numbered statements and proofs.

In the Brussels Museum, Dollo began immediately to study the fossil reptiles, and his first paper, published in October 1882, was a description of Mosasaurus and a new allied genus, Pterycollasarrus. The finest specimens of Mosasaurians in Europe were found in the Upper Cretaceous rocks of Belgium, and Dollo in subsequent years made many contributions to our knowledge of these extinct sea reptiles. In 1882, however, much progress had already been made in extracting from the rock the wonderful skeletons of Iguanodon and other reptiles which had been discovered four years previously in the Wealden of Bernissart, near Mons. Dollo was then entrusted with the study of this collection, and he soon produced a series of
"Notes" in the Museum bulletin which described whole skeletons of Iguanodon for the first time, made known many new facts, and discussed them in a brilliant manner. He also published notes on the associated crocodiles and turties, and the oldest known newt. These papers were intended to be preliminary to an exhaustive monograph on the whole collection which he hoped to prepare, but difficulties arose which unfortunately prevented the accomplishment of the task. Dollo, indeed, was forbidden by the director of the Museum at the time to proceed with his researches on fossil reptiles, and was ordered to pay attention to the fishes. Thus originated his classic paper on the evolution of the Dipnoi, and many other suggestive papers on evolutionary problems which made fundamental advances in the methods of studying fossils. He established the general principle that during evolution "an organism never returns exactly to its former state even if it finds itself placed again in circumstances identical with those through which it has passed". He described this as the irreversibility of evolution, and it is sometimes termed Dollo's law. He also emphasised the importance of 'ethology', or the study of organisms in relation to their natural surroundings, and furnished many striking examples in his later papers. His last paper, on the carpus and tarsus, published in 1929 , fully maintained his old standards, and was written in the characteristic logical form.

Dollo had many ardent admirers among contemporary biologists, and a distinguished group of his friends made contributions to the first volume of a new serial Palcoobiologica which was published by Prof. O. Abel in Vienna in 1928 in honour of his seventieth birthday. He was a foreign member of the Linnean, Geological, and Zoological Societies of London, and was awarded the Murchison Medal of the Geological Society in 1912. He was also an honorary Sc.D. of Cambridge. He was professor in the University of Brussels, and member of the Royal Belgian Academy. He was also a corresponding member of the Academies of Science of Berlin, Munich, and New York. He was an acknowledged leader, with a devoted following in the new generation.

A. S. W.

No. 3219, Vor. 128] 